The University of Southern Mississippi The Aquila Digital Community

Faculty Publications

Winter 12-1-1998

\title{
Growing Up Poor: Home, School and Street in London 1870-1914
}

L. Margaret Barnett

University of Southern Mississippi

Follow this and additional works at: https://aquila.usm.edu/fac_pubs

Part of the History Commons

\section{Recommended Citation}

Barnett, L. M. (1998). Growing Up Poor: Home, School and Street in London 1870-1914. Albion, 30(4), 717-719.

Available at: https://aquila.usm.edu/fac_pubs/5158

This Book Review is brought to you for free and open access by The Aquila Digital Community. It has been accepted for inclusion in Faculty

Publications by an authorized administrator of The Aquila Digital Community. For more information, please contact Joshua.Cromwell@usm.edu. 
After reading this catalogue, one gets the curious impression that, though fairy art, theater, and literature had a secure place in nineteenth-century British culture, these fantasy genres still remained a segregated enclave of entertainment within that culture. For the most part, Victorian Fairy Painting is a conservative appraisal. I sought in vain for the kind of imaginative cross-cultural viewpoints that have been a prominent feature of Victorian studies in the last twenty years in the work of such scholars as Jack Zipes and Marina Warner on the fairy tale, Peter Gay on Victorian sexuality, and Susan P. Casteras on gender imagery. The catalogue hints at, yet never fully explores, the significance of fairy painting as a vital part of the British academic art system and of Victorian culture as a whole.

Allegheny College

RICHARD A. SCHINDLER

Anna Davin. Growing Up Poor: Home, School, and Street in London 1870-1914. London: Rivers Oram Press; dist. by New York University Press, New York, N.Y. 1996. Pp. xiv, 289. \$19.50 paper. ISBN 1-85489-063-8.

Gretchen R. Galbraith. Reading Lives: Reconstructing Childhood, Books, and Schools in Britain, 1870-1920. New York: St. Martin's Press. 1997. Pp. viii, 184. \$39.95. ISBN 0-312-12143-1.

Although everyone starts life as a child, the concept of childhood as a stage of development defined by age and shared experiences is relatively recent. Both books take as their starting point the year in which that differentiation of childhood took root in Britain. The Forster Education Act of 1870 led to the opening of publicly funded institutions known as Board Schools, which provided elementary education throughout the country. Although compulsory attendance came later, every child now could, and was expected to, go to school. This introduced a common element into people's lives that we take for granted today. New standard curricula reinforced that trend. For a few years at least, children with parents from different walks of life would spend their days studying similar subjects and reading similar texts in an environment removed from the adult sphere of work and family responsibility. Over the years, the state-mandated school-leaving age rose, and the duration of childhood steadily lengthened. As Anna Davin and Gretchen Galbraith explain, though, this process was not without its growing pains.

Davin's Growing Up Poor provides an engrossing account of what it meant to be a child during the first few decades of universal education. The author begins by assessing general lifestyles in the poorest working-class districts of London. The overall picture is familiar. To contemporary middle-class reformers, the children's lives exhibited a degree of domestic instability that school would help moderate. Most of the youngsters were born to parents whose own lack of education and vocational skills had condemned them to a lifetime of financial insecurity and impermanence. Fluctuations in income caused the larger-than-average families to move often, from one cramped squalid lodging to another. Evictions for non-payment of rent were common, but people were equally quick to move to better places when more money became available. Davin found little evidence that this distressed the children. While their homes may have changed, their neighborhood generally remained the same. Further stability was derived from the strong sense of community, a social trait that endured for decades longer, as World War II evacuation officials were to discover. To assess the impact of change in this period, Davin therefore argues, one must find out what the 
children themselves considered normal, rather than compare their experiences to middleclass ideals.

One of the most interesting features of this book is the degree to which the children speak for themselves. Besides culling a large number of published and unpublished written memoirs, the author draws on an extensive collection of oral histories collected during the 1970s. Davin herself recorded some of these. She uses them skillfully, interweaving childhood memories with outsiders' observations taken from more frequently used sources, such as official reports by educators, health inspectors, and parliamentary commissioners.

The personal accounts remind us that the gloomy pictures of the Victorian and Edwardian working classes that typically find their way into history texts do not cover all aspects of child life. Davin's subjects made frequent mention of loving mothers and of the friendships, games, and treats that brightened their young world. Although outsiders may have frowned, the street too provided as much fun as the schoolyard. While the memoirs and oral histories suggest the need for a reassessment of emotional well-being, they nevertheless confirm established views about the physical discomfort poor children suffered and about abuses from which the school offered temporary escape. All the usual complaints about conditions in the home are here, notably the lack of space and poor hygiene. Davin also picked up on less frequently discussed domestic problems, such as inadequate furniture. She includes an interesting section on bedding. What did children sleep on in a home that might contain only one or two proper beds for a family of eight? The availability by the 1890s of collapsible chair-beds and folding beds that could be set up in living rooms and kitchens was a boon for poor families. Even so, there were vivid memories of uncomfortable makeshift bunks made from furniture normally used for other purposes and of the impossibility of getting enough rest amidst the continuing noise and bustle of the adult day.

As Davin and Galbraith both point out, it was not just lack of sleep and of a quiet place to study that made it difficult for many poor children to take full advantage of the schooling offered them by the new legislation. Resistance to the law by parents and familial demands placed on children were even more important. The main problem was money. Although compulsory, schooling was not at first free. School fees in London averaged about two pence a week per child; some were as much as sixpence. Poor parents were hard pressed to find such a sum, especially since they lost the wages the child could earm by work during the day. Galbraith's Reading Lives is particularly good in conveying the frustration felt by truant officers and court officials in their quest to persuade both parents and children of the necessity of obeying the law and of the longterm value of an education. The issue became politicized, providing newly formed socialist parties with a plank for their platforms. By 1892, Galbraith notes, most school districts in London had abolished fees in an effort to defuse the situation. This did not, however, settle the issue of child labor.

Davin devotes about a third of her book to this topic and pays special attention to the plight of girls. Although Growing Up Poor is not by any means narrowly focused on one gender, it could well be used as a text in a course on women's history because of the fresh insights it offers into the lives of working-class women and female children. Child labor, at least among the poor, was perfectly acceptable in the Victorian and Edwardian eras. All children were expected to contribute to the family's well being by working both at chores in the home and at paid employment after school or on weekends. Davin found, however, that boys' jobs tended to take them out of the house more, to be less time consuming, and to involve less drudgery. Boys might clean cutlery, chop and sell wood for kindling, run errands, or deliver goods for shops and factories. Girls more frequently earned money by 
running errands, baby sitting, and housework. Within the family, both boys and girls might have to mind younger siblings, but that duty usually fell to the eldest girl in the family, who often served as a family drudge. In homes where children arrived at too frequent intervals for an exhausted mother to manage alone, some school-age girls were seldom without a baby to look after throughout the day. Schools tried to deal with this problem by providing nursery rooms in which the student could leave the baby while she attended classes. The sheer amount of work involved in cooking and housework in this era placed additional burdens on these girls, who were often kept home from school on washdays and any other time when the mother needed an extra pair of hands. The effect on the girls' education can be imagined. A curriculum that sacrificed academic coursework for domestic science for girls did not improve matters.

Both books comment on the Board School curriculum, which was designed to "civilize" as well as instruct the children of the poor. Again, Reading Lives is particularly strong in this area. Galbraith not only provides a wealth of information about coursework and reading materials but breaks new ground with an analysis of the controversy that arose in the early 1880 s over the bad effect the new schooling was allegedly having on the health of children and teachers. Educators, doctors, politicians, and the popular press all joined in the debate that raged throughout the $1880 \mathrm{~s}$. Critics claimed that overwork caused teachers to collapse with nervous breakdowns and students to fall sick with meningitis and other potentially fatal diseases. With national degeneration becoming an issue, some people even wondered if heredity rendered poor children unfit to withstand the pressure of compulsory education.

As its title suggests, Galbraith's book covers more than the social and scholastic consequences of the Forster Act; it also has much to say about the reading habits of middle- and upper-class children of the era. There is an excellent chapter on children's magazines that analyzes the universal appeal of the highly successful Little Folks. Galbraith uses this magazine to establish adult attitudes toward children as well as changing tastes of children over time and differing reading habits of boys and girls. Another good chapter looks at contemporary opinion about the ideal content and purpose of fiction for children.

Growing Up Poor and Reading Lives are eminently worthy books. Still, there are a few areas of criticism. Davin disappoints by not including a separate discussion of poor children's eating habits. Diet, after all, was one factor that differentiated social classes, and it had a marked impact on a child's ability to perform in the classroom. In her analysis of the topics covered in the memoirs she used, Galbraith notes that food "ranked high" among people from working-class backgrounds (p. 11). For its part, Reading Lives is too diverse in content. Interesting though it is, the material on Board Schools does not fit comfortably with the coverage of children's fiction. Neither problem detracts from the overall value of the works, however. Davin and Galbraith are to be commended for having produced such well-researched, informative, and readable studies.

University of Southern Mississippi

L. MARgaret BARNetT

Douglas Newton. British Policy and the Weimar Republic, 1918-1919. New York: Oxford University Press. 1997. Pp. xiii, 481. \$95.00. ISBN 0-19-8203-14-4.

Writing in an unimpeachable but now somewhat unfashionable historiographical tradition, Douglas Newton has done his best to deliver Britain's role in the making of the Versailles Treaty into the hands of closet Rankeans. On the one hand he has read everything in print 